
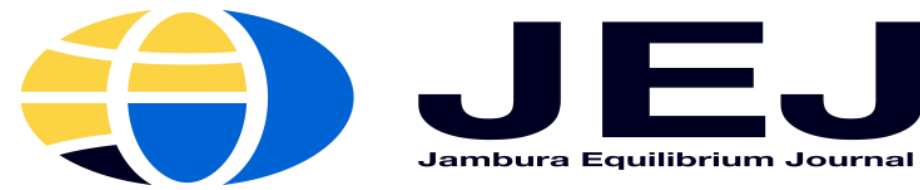

Volume 3. Issue 1. January 2021

P-ISSN 2655-9110

E-ISSN 2656-0445

http://ejurnal.ung.ac.id/index.php/equij

\title{
Analysis of the Viability of Fiscal and Monetary Policies on the Recovery of Household Consumption Expenditures Because of the Covid-19 Pandemic
}

Fahrul Riza ${ }^{1}$, William Wiriyanata ${ }^{2}$

Management Study Program, Faculty of Social Sciences and Humanities, Universitas Bunda Mulia, Jakarta, Indonesia $^{1,2}$

Abstract: The Covid-19 outbreak disrupted economic activity in almost all countries. The Indonesian economy entered a recession phase as a result of the continued contraction in economic growth in the second and third quarters of 2020. According to Keynesian economic theory, the combination of fiscal policy and monetary policy was more effective in recovering the economy from the crisis, this study aims to measure the effect of government spending, money supply, inflation and interest rates on aggregate household consumption expenditure. This study used a quantitative method, using monthly time series data from January 2015 to December 2020. The data were analyzed using the Vector Error Correction Model (VECM). The results show that government spending has a negative impact on household aggregate expenditure in the long run meanwhile interest rate has a positive impact on household consumption expenditure. Inflation do not affect aggregate household consumption expenditure, both in the short and long term. The results of the analysis are useful for evaluating the policies taken by the government to overcome the economic crisis due to the spread of the Covid-19 outbreak. The government increases aggregate expenditure to cover the decline in household aggregate consumption expenditure due to a decrease in household real income. Then expansionary monetary policy in the long run will increase aggregate demand. Therefore, the Ministry of Finance together with Bank Indonesia needs to design other policies that will have a positive impact on economic recovery in the short term. This study has not included other macro indicators that affect household consumption expenditures such as unemployment, taxes and the household marginal propensity to saving (MPS).

\section{Keywords: Household Aggregate Expenditure; Government Expenditure; Inflation; VECM}

\section{INTRODUCTION}

The spread of the Covid-19 virus on a global scale has reduced economic activity in almost all countries in the world; even many of these countries are now experiencing recession due to the continued decline in economic growth. Countries that experienced a fairly high contraction included Singapore $(41.2 \%)$, the United States (10\%), and the United Kingdom $(15 \%)$. The global economy contracted -5.2 per cent, Indonesia -0.3 percent (Nainggolan, 2020).

Indonesia's Gross Domestic Product started to recover in Q4, although 
the recovery has not yet returned to its original level (Julita, 2021). Restrictions on the economic activity enforced to reduce the rate of virus transmission have the effect of decreasing the circulation of money in the economy, which results in an increase in the unemployment rate and a decrease in household income.

Data released by the Indonesian Central Bureau of Statistics shows that almost all sectors of economy experienced a decline in income up to 80 per cent. The tourism and transportation sectors were most affected by the Covid-19 pandemic. The decline in company income forces company owners to reduce labor and demands for raw materials. The unemployment rate increases causing household income and aggregate household expenditure to fall.

\section{Household}

consumption, government consumption, investment spending, exports and imports are the five important factors that determine the economic growth of a country (Dornbusch, Fischer, \& Startz, 2018). Household and government consumption expenditures are the most effective components to overcome the economic downturn in the short term (Nuru, 2020).

Household consumption expenditure has a large share in the component of Indonesia's GDP (above 50 percent). Economists agree that, in this time of crisis, the component of expenditure that is most expected to support an increase in GDP is consumption. Increased consumption will stimulate investment demand, and economic activity will gradually recover. Keynes in his theory postulated that in order to recover the economy from a crisis, it is necessary to restore aggregate demand to stimulate aggregate supply (Dornbusch, Fischer, \& Startz, 2018).

Recognizing the important role of aggregate household consumption in accelerating Indonesia's economic recovery, the Ministry of Finance together with Bank Indonesia established a National Economic Recovery (PEN) program which contains a comprehensive fiscal and monetary policy package. The formula for economic recovery targeted by PEN is aimed at three things, namely: increasing domestic consumption (household, corporate and government); increase business activities; economic stabilization and monetary expansion. The three steps are carried out simultaneously and in synergy between the government and financial institutions (Nainggolan, 2020).

Keynes postulates that consumption expenditure is influenced by disposable income and Marginal Propensity to Consume (MPC) (Dornbusch, Fischer, \& Startz, 2018). An increase in income will increase consumption expenditure, the MPC rate determines the additional consumption expenditure resulting from additional income. The rate of inflation and the deposits interest rate affect income allocated to consumption (Springer, 1977). The expected inflation will affect the allocation of consumption expenditures for durable and non-durable goods. When the expected inflation is low, the expenditure allocation for durable goods increases, vice versa. Thus, the expected inflation has a two-way effect on consumption expenditure (Springer, 1977).

Indonesian Central Statistics Agency (BPS) has released inflation data throughout 2020 at 1.68 percent This figure is the lowest in history and far below the government's inflation target of 3 percent plus minus 1 percent (Wiguna, 2021). The lowest inflation is due to weak purchasing power according to the opinion of economists (Fitriani, 2020).

To stimulate consumption and investment spending, The Ministry of Finance issued 
an expansive fiscal policy which prioritized government spending allocations to deal with the recovery of economic sectors affected by the pandemic. The expenditure side increases for subsidies and the handling of the pandemic, while the income side decreases for tax incentives, the budget deficit increases.

On the monetary side, Bank Indonesia has issued an expansive monetary policy by cutting interest rates to 3.75 percent. The goal is that depositors are reluctant to save their money in the bank, use the money to shop or invest, increase the money supply. However, it appears that the policy has not been able to stimulate a significant increase in aggregate expenditure.

The purpose of this study is to determine the effect of expansionary fiscal and monetary policies, the setting of interest rates and the inflation rate on aggregate household consumption expenditure for the period January 2015 to December 2020. Knowing the level of effectiveness of each policy is expected to be a guideline for the government in taking economic policies to deal with the economic crisis in Indonesia caused by the outbreak of the spread of the Covid-19 virus.

\section{The Effect of Expansive Fiscal Policy on Aggregate Demand.}

Fiscal policy is government intervention to maintain economic stability. Fiscal policy instruments consist of government spending and taxes (Dornbusch, Fischer, \& Startz, 2018). In a sluggish economic condition, an increase in the share of government spending is a stimulus for the economy. On the other hand, the government provides tax breaks to ease the burden of spending. So those taxes as a source of government revenue cannot be collected optimally in times of economic downturn. Expansive fiscal policy leads to a budget deficit.

Fiscal deficit completely influences economic process through the multiplier factor impact that results in higher economic growth: savings, will increase the demand for cash, and stimulates investment, therefore generating financial deficit therefore encompasses a useful impact, and then a deficit at the correct time and manner is vital for the economy (Zoto \& Berisha, 2016). (Oo, 2019) found a significant relationship between the country's fiscal deficit and economic growth in Myanmar during 1979 to 2016.

$\mathrm{H1}$ : There is an effect of expansionary fiscal policy on household aggregate consumption expenditure.

\section{The Effect of Expansive Monetary Policy on Aggregate Demand}

The money supply affects aggregate demand. The central bank (BI) sets a reference interest rate to control the money supply in the economy (Fischer \& Modigliani, 1980). Fisher's theory states that the real interest rate affects consumption expenditure. Low interest rates will increase the money supply, conversely, high interest rates will reduce the money supply. The money supply is not solely due to Central Bank policy. Keynes argued that the demand for cash for precautionary purposes depends on household income. The higher a household's income level, the greater they ask for cash. A person or society whose income level is high usually makes more transactions than someone whose income is low.

Monetary policy affects interest rates and therefore the accessible amount of loanable funds, that successively affects many elements of mixture demand. Tight financial policy that ends up in higher interest rates and a scale reduce amount of loanable funds can reduce two elements of mixture demand. Business investment can 
decline as a result of it's less enticing for companies to borrow cash, and even companies that have cash can notice that, with higher interest rates, it's comparatively additional enticing to place those funds associate degree exceedingly in a very\} monetary investment than to create an investment in physical capital. additionally, higher interest rates can discourage client borrowing for high-ticket things like homes and cars. Conversely, loose or expansionary financial policy that ends up in lower interest rates and a better amount of loanable funds can tend to extend business investment and client borrowing for high-ticket things.

$\mathrm{H} 2$ : There is an effect of expansionary monetary policy on household aggregate consumption expenditure.

\section{The Effect of Inflation on Aggregate Demand}

Inflation is an increase in the price level that occurs generally and continuously over a period of time. A price increase that occurs specifically for one or two goods cannot be defined as inflation unless the price increase occurs widely and has an effect on the prices of other commodities (Muttaqim, Hamdani, \& Husin, 2019). Inflation plays a role in changes in the level of public consumption. Inflation has a significant effect on consumption. If inflation increases, then the ability of public consumption will decrease, and if inflation decreases, the ability of public consumption will be better (Nagayasu, 2017). Changes in the inflation rate can affect the rate of development of consumption. On this basis, the following hypothesis is compiled.
H3: There is an effect of inflation rate on household aggregate consumption expenditure.

\section{METHODOLOGY}

The study employs monthly data from January 2015 to December 2020. Data were extracted from several sources, which include the Economic Survey released by Central Bureau of Statistics (BPS) Indonesian Economic and Financial Statistics (SEKI), released by Bank of Indonesia. The household consumption expenditure (KRT) is the total national consumption expenditure of households calculated using constant prices for the 2010 base year. Government expenditure (Gov) is the total national government expenditure calculated using the 2010 base year. Consumption and government expenditures are released on a quarterly basis by the Central Statistics Agency. Because the research was conducted using monthly data, we interpolated quarterly to monthly data using e-views. Interest rate (IR) is the benchmark interest rate released by Bank Indonesia periodically. Inflation is the general average rate of increase in prices that occurs at the national level. This study uses the Vector Error Correction Model (VECM) to examine the effect of research variables.

\section{RESULTS}

Table 1 presents the descriptive statistical results of the research variables. The total sample of observations was 72 months, from January 2015 to December 2020;

Table 1. Descriptive Statistics

\begin{tabular}{lcccc}
\hline & INFLASI & IR & KRT & GOV \\
\hline Mean & 3.664167 & 5.510417 & 454939.5 & 177645.1
\end{tabular}


Analysis of the Viability of Fiscal and Monetary Policies on the Recovery of Household Consumption Expenditures Because of the Covid-19 Pandemic

Email: riza.fahrul@gmail.com

\begin{tabular}{lcccc}
\hline Median & 3.315000 & 5.125000 & 457767.1 & 176176.4 \\
Maximum & 7.260000 & 7.750000 & 506539.7 & 231043.7 \\
Minimum & 1.320000 & 3.750000 & 395777.9 & 150140.9 \\
Std. Dev. & 1.471181 & 1.214233 & 32606.78 & 23252.71 \\
Skewness & 1.136564 & 0.492895 & -0.187004 & 0.496616 \\
Kurtosis & 3.830180 & 1.920935 & 1.860508 & 2.208576 \\
\hline & & & & \\
Jarque-Bera & 17.56893 & 6.408483 & 4.314974 & 4.838588 \\
Probability & 0.000153 & 0.040590 & 0.115615 & 0.088984 \\
& & & & \\
Sum & 263.8200 & 396.7500 & 32755641 & 12790447 \\
Sum Sq. Dev. & 153.6706 & 104.6797 & $7.55 \mathrm{E}+10$ & $3.84 \mathrm{E}+10$ \\
Observations & & & & \\
\hline
\end{tabular}

Source: Data were processing with E-views 9

The average inflation during the study period was 3.6 percent, the average interest rate was 5.5 percent, average household aggregate consumption expenditure was IDR 454 trillion and average government expenditure was IDR 177 trillion.

\section{Unit Root Test}

Analysis with VECM is based on time series data which is not stationary but co-integrated. To check the stationary of the data, the unit root test can be used, with the test statistic used is Phillips-Perron The stationary test values are presented in Table 2.

Table 2. Phillips-Perron test results

\begin{tabular}{|c|c|c|c|}
\hline \multicolumn{2}{|l|}{ Method } & Statistic & Prob. ${ }^{* *}$ \\
\hline \multicolumn{2}{|c|}{ PP - Fisher Chi-square } & 92.1353 & 0.0000 \\
\hline \multicolumn{2}{|l|}{ PP - Choi Z-stat } & -8.00895 & 0.0000 \\
\hline \multicolumn{4}{|c|}{$\begin{array}{l}{ }^{* *} \text { Probabilities for Fisher tests are computed using an } \\
\text { asymptotic Chi-square distribution. All other tests } \\
\text { assume asymptotic normality. }\end{array}$} \\
\hline \multicolumn{4}{|c|}{ Intermediate Phillips-Perron test results D(GROUP01) } \\
\hline Series & Prob. & Bandwidth & Obs \\
\hline $\mathrm{D}(\mathrm{KRT})$ & 0.0041 & 9.0 & 70 \\
\hline $\mathrm{D}(\mathrm{GOV})$ & 0.0178 & 3.0 & 70 \\
\hline $\mathrm{D}(\mathrm{M})$ & 0.0001 & 3.0 & 70 \\
\hline $\mathrm{D}(\mathrm{INFLASI})$ & $0.00 c^{n}$ & 6.0 & 70 \\
\hline $\mathrm{D}(\mathrm{IR})$ & $0.00 C \quad 44$ & 3.0 & 70 \\
\hline
\end{tabular}

Source: Data were processing with E-views 9

The values in the Phillip-Perron table show all series are stationary at 1 st difference.
Determine the optimum lag in the VAR model 
The optimal lag length test aims to eliminate autocorrelation. The optimal lag length will be searched using the available information criteria.

Table 3. Lag Selection Criteria

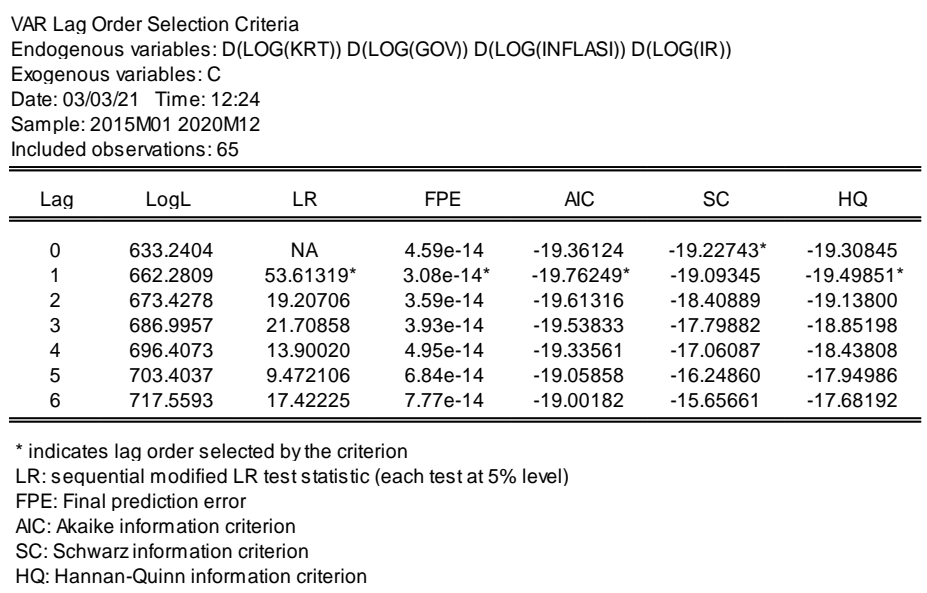

Source: Data were processing with E-views 9

In determining the optimal lag, there are several criteria, one of the criteria by using Akaike criteria (Gujarati, 2003). The test results with the lag selection criteria obtained the optimum lag length is 1 (Table 3). The parameters of the VAR model with an optimum lag of 1 are presented in table 4. T-statistics for D ( $\mathrm{Log}$ (KRT (-1)) of 5.06 is significant at alpha
$<0.000$. Thus, it can be concluded that the aggregate expenditure of household consumption in the previous period greatly affects the aggregate expenditure of household consumption in the following period. The table also shows that government spending (Gov), interest rates (IR) and inflation do not have a significant effect on aggregate household consumption expenditure.

Table 4. VAR Model with Lag 1 
Analysis of the Viability of Fiscal and Monetary Policies on the Recovery of Household Consumption Expenditures Because of the Covid-19 Pandemic

Email: riza.fahrul@gmail.com

\begin{tabular}{|c|c|c|c|c|}
\hline & $D(L O G(K R T))$ & $D(L O G(G O V))$ & D(LOG(INFLA... & $\mathrm{D}(\mathrm{LOG}(\mathrm{IR}))$ \\
\hline \multirow[t]{2}{*}{$\mathrm{D}(\operatorname{LOG}(\operatorname{KRT}(-1)))$} & $\begin{array}{l}0.527721 \\
(0.10424)\end{array}$ & $\begin{array}{r}-0.026994 \\
(0.04973)\end{array}$ & $\begin{array}{l}1.339666 \\
(1.29149)\end{array}$ & $\begin{array}{r}-0.399842 \\
(0.46535)\end{array}$ \\
\hline & [5.06277] & {$[-0.542831$} & I 1.037311 & {$[-0.85923]$} \\
\hline \multirow[t]{2}{*}{$\mathrm{D}(\operatorname{LOG}(\mathrm{GOM}(-1)))$} & -0.145322 & 0.571042 & 0.871065 & -0.446432 \\
\hline & {$[-0.68246]$} & [ 5.621251 & $\begin{array}{r}(2.63832) \\
\text { (0.330161 }\end{array}$ & {$[-0.46961]$} \\
\hline \multirow[t]{3}{*}{ D(LOG(INFLASI (-1))) } & -0.001483 & 0.000429 & 0.189476 & 0.034502 \\
\hline & $(0.00976)$ & $(0.00465)$ & $(0.12087)$ & (0.04355) \\
\hline & {$[-0.151971$} & โ 0.092181 & I 1.567591 & โ0.792191 \\
\hline \multirow[t]{2}{*}{$D(\operatorname{LOG}(\operatorname{IR}(-1)))$} & 0.036277 & -0.008094 & -0.027582 & 0.334091 \\
\hline & $\begin{array}{l}(0.02589) \\
{[1.40133]}\end{array}$ & $\begin{array}{r}(0.01235) \\
{[-0.65539]}\end{array}$ & $\begin{array}{r}(0.32075) \\
{[-0.08599]}\end{array}$ & $\begin{array}{l}(0.11557) \\
{[2.89075]}\end{array}$ \\
\hline \multirow[t]{2}{*}{ C } & 0.002512 & 0.002759 & -0.024268 & -0.001881 \\
\hline & $\begin{array}{l}(0.00169) \\
{[1.48974]}\end{array}$ & $\begin{array}{l}(0.00080) \\
{[3.42971]}\end{array}$ & $\begin{array}{r}(0.02089) \\
{[-1.16149]}\end{array}$ & $\begin{array}{r}(0.00753) \\
{[-0.24988]}\end{array}$ \\
\hline R-squared & 0.310631 & 0.345234 & 0.050786 & 0.136631 \\
\hline \multirow{2}{*}{$\begin{array}{l}\text { Adi. R-s quared } \\
\text { Sum sq. resids }\end{array}$} & 0.268209 & 0.304941 & -0.007627 & 0.083501 \\
\hline & 0.004696 & 0.001069 & 0.720936 & 0.093600 \\
\hline S.E. equation & 0.008500 & 0.004055 & 0.105315 & 0.037947 \\
\hline $\begin{array}{l}\text { F-statistic } \\
\text { Log likelihood }\end{array}$ & 7.322292 & 8.568030 & 0.869434 & 2.571627 \\
\hline \multirow{2}{*}{$\begin{array}{l}\text { Log likelihood } \\
\text { Akaike AIC }\end{array}$} & 237.0064 & 288.8131 & 60.82379 & 132.2769 \\
\hline & -6.628753 & -8.108944 & -1.594965 & -3.636484 \\
\hline \multirow{2}{*}{$\begin{array}{l}\text { Schwarz SC } \\
\text { Mean dependent }\end{array}$} & -6.468146 & -7.948338 & -1.434358 & -3.475877 \\
\hline & 0.002859 & 0.006145 & -0.018860 & -0.009902 \\
\hline S.D. dependent & 0.009936 & 0.004864 & 0.104916 & 0.039638 \\
\hline \multirow{2}{*}{\multicolumn{2}{|c|}{$\begin{array}{l}\text { Determinant resid covariance (dof adi.) } \\
\text { Determinant resid covariance }\end{array}$}} & 1. $86 E-14$ & & \\
\hline & & $1.38 E-14$ & & \\
\hline \multicolumn{2}{|l|}{ Log likelihood } & 719.6968 & & \\
\hline \multicolumn{2}{|c|}{ Akaike information criterion } & -19.99134 & & \\
\hline \multicolumn{2}{|l|}{ Schwarz criterion } & -19.34891 & & \\
\hline
\end{tabular}

Estimation of the VAR equation system that has been formed needs to be tested for stability through the VAR stability condition check in the form of the roots of a characteristic polynomial for all variables used multiplied by the lag amount of each VAR, before moving on to the next analysis. The VAR stability test is important so that the IRF and FEVD analysis is valid. The VAR model is stable when all of its roots have a modulus of less than one. In this study, based at the VAR stability test shown, it was concluded that the VAR stability estimate to be used for the IRF and FEVD analysis was stable because the modulus range was $<1$. 
Table 5. VAR model stability test

Source: Data were processing with E-views 9

Roots of Characteristic Polynomial

Endogenous variables: D(KRT) D(GOV) D(INFLASI) D...

Exogenous variables:

Lag specification: 11

Date: 03/06/21 Time: 11:45

\begin{tabular}{cc}
\hline \hline Root & Modulus \\
\hline \hline 0.877635 & 0.877635 \\
0.522696 & 0.522696 \\
$0.300257-0.059845 \mathrm{i}$ & 0.306163 \\
$0.300257+0.059845 \mathrm{i}$ & 0.306163 \\
\hline \hline
\end{tabular}

No root lies outside the unit circle.

VAR satis fies the stability condition.

\section{Granger's Cointegration Test}

The next stage of the test is Granger's cointegration test to see the relationship of all variables in the long run. Using the VAR model, the optimum model is lag 1. Causality test is applied to the lag 1 model. The causality test uses the Granger causality test on the VAR model with a lag of 1 . Table 3 displays the results of VAR model with Lag 1. The VAR model shows that expansionary fiscal-monetary policy and inflation do not have a significant effect on aggregate household consumption expenditure in Indonesia. The VAR model confirms that the previous period's household consumption aggregate expenditure affects the following month's aggregate consumption expenditure. Table 4 , indicates that a null hypothesis to causality test row, fiscal policy instruments, namely Government Expenditure does not affects the Aggregate Household Consumption (KRT), interest rate (IR) and inflation a short period of time. Monetary policy instruments (IR) does not affect Aggregate Household Consumption (KRT), Government Expenditure (Gov) and inflation. Inflation affect interest rate (IR) but does not affected Aggregate Household Consumption (KRT), Government Expenditure (Gov). In this case the fiscal and monetary policy in the economy of Indonesia is the response from the pandemic of covid-19 through a variable if interest rate, prove that the economy of Indonesia meets the criteria as a small open economy. 
Analysis of the Viability of Fiscal and Monetary Policies on the Recovery of Household Consumption Expenditures Because of the Covid-19 Pandemic

Email: riza.fahrul@gmail.com

Table 6. Causality Test

\begin{tabular}{|c|c|c|c|}
\hline Null Hypothes is: & Obs & F-Statistic & Prob. \\
\hline $\begin{array}{l}\text { GOV does not Granger Cause KRT } \\
\text { KRT does not Granger Cause GOV }\end{array}$ & 71 & $\begin{array}{l}0.00494 \\
1.40853\end{array}$ & $\begin{array}{l}0.9442 \\
0.2394\end{array}$ \\
\hline $\begin{array}{l}\text { IR does not Granger Cause KRT } \\
\text { KRT does not Granger Cause IR }\end{array}$ & 71 & $\begin{array}{l}0.00196 \\
0.03751\end{array}$ & $\begin{array}{l}0.9648 \\
0.8470\end{array}$ \\
\hline $\begin{array}{l}\text { INFLASI does not Granger Cause KRT } \\
\text { KRT does not Granger Cause INFLASI }\end{array}$ & 71 & $\begin{array}{l}0.56407 \\
0.45546\end{array}$ & $\begin{array}{l}0.4552 \\
0.5020\end{array}$ \\
\hline $\begin{array}{l}\text { IR does not Granger Cause GOV } \\
\text { GOV does not Granger Cause IR }\end{array}$ & 71 & $\begin{array}{l}19.0872 \\
0.02893\end{array}$ & $\begin{array}{l}4 . E-05 \\
0.8655\end{array}$ \\
\hline $\begin{array}{l}\text { INFLASI does not Granger Cause GOV } \\
\text { GOV does not Granger Cause INFLASI }\end{array}$ & 71 & $\begin{array}{l}2.66878 \\
1.54768\end{array}$ & $\begin{array}{l}0.1070 \\
0.2178\end{array}$ \\
\hline $\begin{array}{l}\text { INFLASI does not Granger Cause IR } \\
\text { IR does not Granger Cause INFLASI }\end{array}$ & 71 & $\begin{array}{l}4.63875 \\
0.00368\end{array}$ & $\begin{array}{l}0.0348 \\
0.9518\end{array}$ \\
\hline
\end{tabular}

Source: Data were processing with E-views 9

\section{Vector Error Correction Model}

The VECM estimation results will obtain a short-term and long-term relationship between consumption, exports, gross domestic income and imports. In this estimate, aggregate household consumption expenditure is the dependent variable, while the independent variable consists of government expenditure (gov), interest rate (ir) and inflation. The VECM regression equation to analyze the shortterm and long-term effects of the dependent variable on the independent variable is as follows:

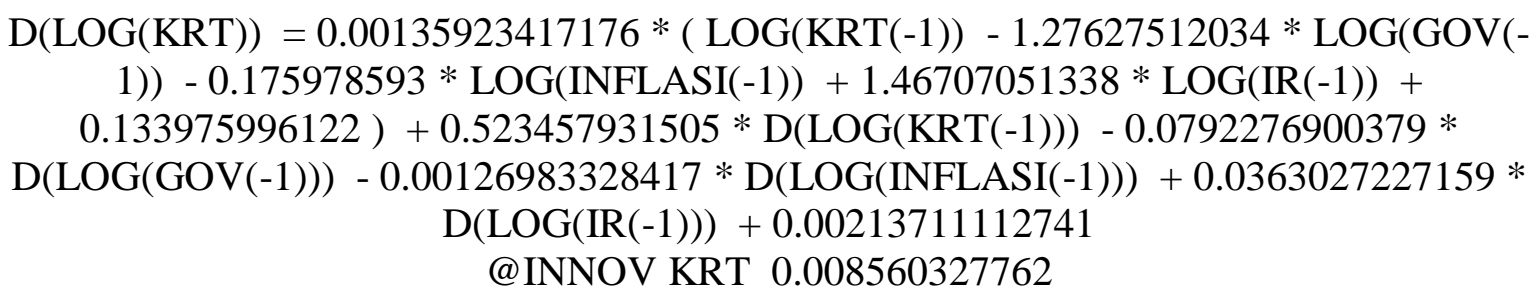




\section{Tabel 7. Vector Error Correction Estimate}

\begin{tabular}{|c|c|c|c|c|}
\hline 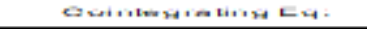 & GะWIEนT1 & & & \\
\hline LOCS(KRT T $(-1))$ & 1.000000 & & & \\
\hline LOCA $(\cos V(-1))$ & $\begin{array}{r}-1.278275 \\
(0.61427) \\
(-2.077701\end{array}$ & & & \\
\hline LOCE INFLASI $(-1))$ & $\begin{array}{r}-0.175979 \\
(0.22083) \\
1-0.706891\end{array}$ & & & \\
\hline LOCG (IF $(-1))$ & $\begin{array}{r}1.487071 \\
(0.35115) \\
(4.450241\end{array}$ & & & \\
\hline$c$ & 0.135978 & & & \\
\hline Errar Carracition: & $D($ LOCA $(K R T))$ & D(LOCACGON) & DLLOCAINFLA... & $D(L O C$ (IR) $)$ \\
\hline Cointeq 1 & $\begin{array}{r}0.001359 \\
(0.00461) \\
(0.294971\end{array}$ & $\begin{array}{c}-0.008770 \\
(0.00151) \\
(-4.598571\end{array}$ & $\begin{array}{l}0.009898 \\
(0.05712) \\
(0.175241\end{array}$ & $\begin{array}{c}-0.058706 \\
(0.02001) \\
{[-1.959181}\end{array}$ \\
\hline$D($ LOCA KRET $(-1))$ & $\begin{array}{r}0.523458 \\
(0.10597) \\
{[4.939881}\end{array}$ & $\begin{array}{r}0.000512 \\
(0.04388) \\
(0.011881\end{array}$ & $\begin{array}{r}1.308650 \\
(1.31350) \\
(0.508291\end{array}$ & $\begin{array}{c}-0.278184 \\
(0.48007) \\
(-0.804811\end{array}$ \\
\hline$D(L O C A(C O O V(-1)))$ & $\begin{array}{r}-0.079228 \\
(0.31015) \\
(-0.255451\end{array}$ & $\begin{array}{c}0.144587 \\
(0.12857) \\
\mid 1.128351\end{array}$ & $\begin{array}{r}1.352248 \\
(3.84455) \\
\mid 0.551751\end{array}$ & $\begin{array}{r}-2.352529 \\
(1.34880) \\
{[-1.73248]}\end{array}$ \\
\hline$D(\operatorname{LOCB}(I N F$ LABI $(-1))$ & $\begin{array}{r}-0.001270 \\
(0.00985) \\
(-0.128901\end{array}$ & $\begin{array}{r}-0.000044 \\
(0.00408) \\
(-0.251421\end{array}$ & $\begin{array}{l}0.191025 \\
(0.12211) \\
(1.584581\end{array}$ & $\begin{array}{l}0.028450 \\
(0.04277) \\
(0.864711\end{array}$ \\
\hline$D(\operatorname{LOC}(1 \mathrm{Re}(-1)))$ & $\begin{array}{r}0.0 s e s 0 s \\
(0.02807) \\
11.552451\end{array}$ & $\begin{array}{c}-0.008281 \\
(0.01075) \\
(-0.765531\end{array}$ & $\begin{array}{r}-0.027394 \\
(0.32517) \\
1-0.084771\end{array}$ & $\begin{array}{l}0.353554 \\
(0.115195) \\
12.044571\end{array}$ \\
\hline$c$ & $\begin{array}{r}0.002137 \\
(0.002123 \\
11.007331 \\
\end{array}$ & $\begin{array}{r}0.005179 \\
(0.00000) \\
15.858251 \\
\end{array}$ & $\begin{array}{r}-0.028058 \\
(0.02050) \\
1-1.026531 \\
\end{array}$ & $\begin{array}{r}0.008824 \\
(0.005013 \\
10.058001 \\
\end{array}$ \\
\hline Re-squarad & 0.311587 & 0.507840 & 0.051231 & 0.184544 \\
\hline Ad i. R-a quatread & 0.257783 & 0.489500 & -0.022801 & 0.1208 ses \\
\hline Bum sa-reasids & 0.004850 & 0.000805 & 0.720500 & 0.088406 \\
\hline BE. Equation & 0.008580 & 0.005543 & 0.108110 & $0.0571 \mathrm{Bes}$ \\
\hline & 5.792958 & 1320778 & 0.891170 & 2.808735 \\
\hline Loga likea lithoad & 237.0539 & 208.8048 & 80.84019 & 134.2752 \\
\hline Aktaikes AlC & -8.801540 & -8.385848 & -1.5Besess & -3.sessoos \\
\hline Setiwnarze BC & -8.408812 & -8.173118 & $-1.3741 s s$ & -3.472278 \\
\hline Measan deapeandearnt & 0.002850 & 0.008145 & -0.018860 & -0.000002 \\
\hline B.D. dea peardet rut & 0.005050 & 0.004884 & 0.104018 & 0.035858 \\
\hline 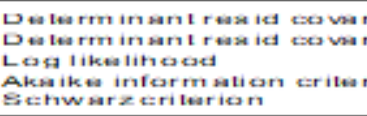 & 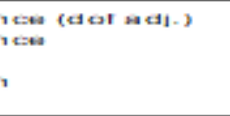 & $\begin{array}{r}1.34 \text { E- } 14 \\
9.40 E-15 \\
733.1384 \\
-20.14881 \\
-19.24741\end{array}$ & & \\
\hline
\end{tabular}

Source: Data were processing with E-views 9

The estimation results using the long-run equation model show that the $\mathrm{t}$ statistics value for Gov -2.077 is greater than -1.97. Thus government spending (Gov) has a significant negative effect on household aggregate expenditure. Government expenditure has the opposite effect on expenditure aggregate household consumption. Thus, the results of this study accept hypothesis one which states that expansionary fiscal policy has an influence on aggregate household consumption expenditure. The $t$-statistic value of the coefficient of the effect of interest rates on aggregate expenditure is 4.43 greater than 1.97. Thus, the results of this study accept the second hypothesis which states that expansionary fiscal policy has a significant effect on aggregate household consumption expenditure. Inflation has no effect in the long or short term. The t-statistic value is less than 1.97. Thus the null hypothesis which states that there is no effect of inflation on aggregate household consumption expenditure is accepted. 


\section{Impulse Response Function}

Figure 1 presents the effects of each dependent variable on the independent variable. Government expenditure (Gov) does not have a significant positive effect on aggregate household consumption expenditure.

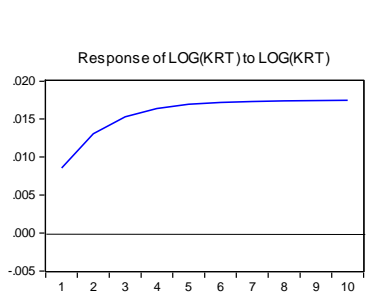

Response to Cholesky One S.D. Innov ations

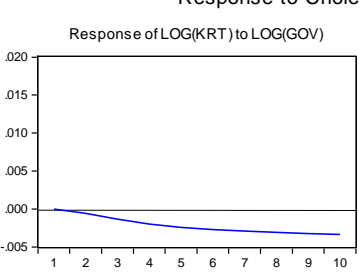

Response ofLOG(KRT) to LOG(INFLAS)
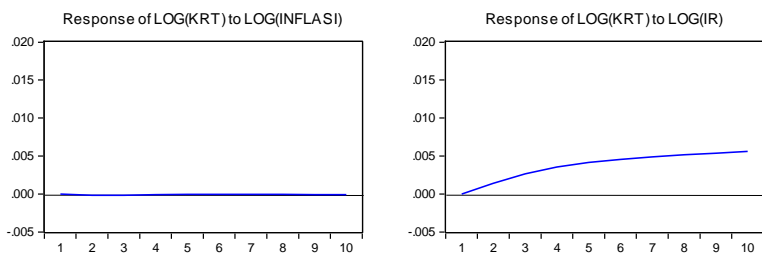

Response of LOG(GOV) to LOG(KRT)

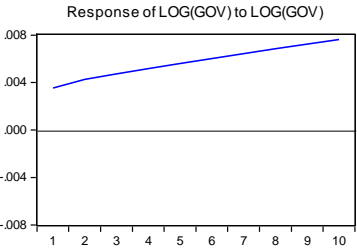

Response of LOG(GOV) to LOG(INFLASI)

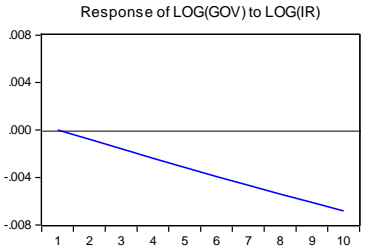

Response of LOG(INFLASI) to LOG(KRT)

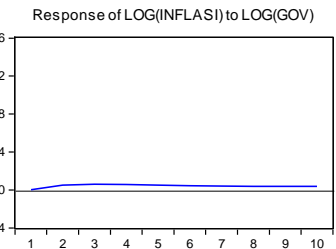

Response ofLOG(NFLASI)toLOGINFLAS)

Response of LOG(NFLAS) to LOG(IR)
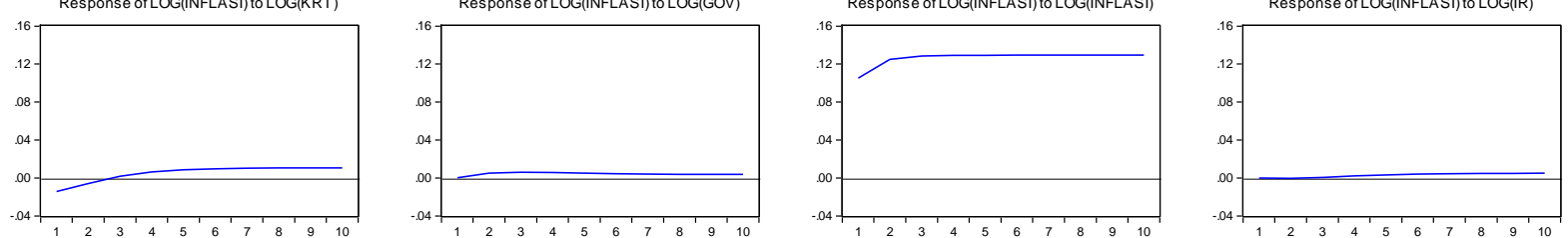

sponse of LOG(IR) to LOG(KRT)

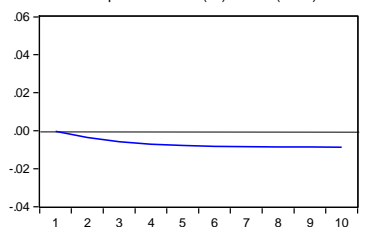

Response of LOG(IR) to LOG(GOV)
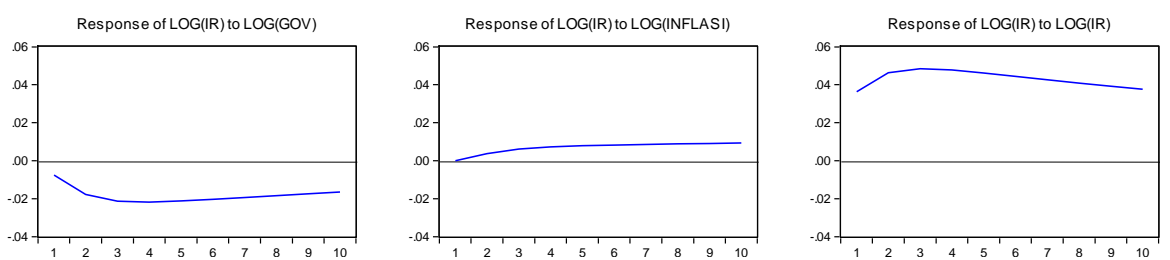

Figure 1. Impulse Response Function (Source: Data were processing with E-views 9)

The lines form a flat pattern with a downward trend. This suggests that in the long run an expansionary fiscal policy will reduce aggregate household consumption expenditure. In the short term, inflation will increase aggregate spending, but after the 4 th period, the pattern flattens out. Thus, in the long run, inflation has no effect on aggregate expenditure. The decline in interest rates resulted in a decrease in aggregate household consumption expenditure, and its effects began to dissipate over the next five months. 
Table 8. Variance Decomposition

\begin{tabular}{|c|c|c|c|c|c|}
\hline \multicolumn{6}{|c|}{ Variance Decomposition of LOG(KRT): } \\
\hline Perio... & S.E. & LOG $(K R T)$ & LOG(GOV) & LOG(INFLA... & LOG(IR) \\
\hline 1 & 0.008560 & 100.0000 & 0.000000 & 0.000000 & 0.000000 \\
\hline 2 & 0.015692 & 99.06548 & 0.136535 & 0.010086 & 0.787901 \\
\hline 3 & 0.022123 & 97.71743 & 0.447261 & 0.010190 & 1.825119 \\
\hline 4 & 0.027839 & 96.43133 & 0.793135 & 0.007859 & 2.767682 \\
\hline 5 & 0.032939 & 95.32366 & 1.109240 & 0.005961 & 3.561142 \\
\hline 6 & 0.037538 & 94.38970 & 1.380757 & 0.004714 & 4.224834 \\
\hline 7 & 0.041737 & 93.59399 & 1.611761 & 0.003916 & 4.790330 \\
\hline 8 & 0.045615 & 92.90086 & 1.810770 & 0.003429 & 5.284943 \\
\hline 9 & 0.049235 & 92.28205 & 1.985763 & 0.003187 & 5.728995 \\
\hline 10 & 0.052642 & 91.71705 & 2.142988 & 0.003161 & 6.136799 \\
\hline
\end{tabular}

Source: Data were processing with E-views 9

Variance decomposition aims to measure the amount of contribution or composition of the influence of each independent variable on the dependent variable. Table 6 shows the effect of each independent variable on the dependent one. All independent variables have not had an effect in period 1 . In period 2, government spending contributed 0.13 percent, inflation was 0.01 percent and interest rates were 0.78 percent. From the same table it can also be seen that interest rates have a more effective effect than government spending.

Regression using the VECM model produces a probability value that does not support CointEq1 for the dependent variable on aggregate household consumption expenditure. Thus, the shortrun effect cannot be estimated using the VECM equation. This finding does not support the research of (Rahutami, 2007) which confirms the existence of a causal relationship between fiscal and monetary policy.

\section{DISCUSSION}

The results of this study are different from research conducted by Safriadi, Masbar, \& Syahnur, (2014) those who found expansionary fiscal policy to be more effective than expansionary monetary policy. However, in his research, the researcher used the GDP variable as the dependent variable. Whereas in this study, the dependent variable is household aggregate consumption expenditure.

Consumption expenditure and interest rate are unidirectional. An increase in the interest rate by 1 percent will increase aggregate household consumption expenditure by 1.46 percent. This finding differs from the results Illahi, Adry, \& Triani (2018), who found the opposite direction between interest rates and consumption expenditure.

The Covid-19 outbreak has had a devastating effect on the global economy. The research results confirm that economic recovery using fiscal and monetary policy instruments will have an effect in the long term, not in the short term. The handling of the economic crisis due to the pandemic requires a large number of funds while the Government cannot fully extract its revenue from taxes. Funding comes from debt which will have an adverse effect on household disposable income in the long run.

Fiscal policy is very vital to the 
sustainability of a country. Because the selection of decisions on policies that have an impact on the progress of a country's economy. Therefore, fiscal policy must be considered carefully by the government so that in the future it does not become a boomerang against the country. This policy can also affect the economic rate of the government along with future sale and purchase which will determine the level of consumption and investment spending. Failure to do so will also result in economic fluctuations and create major turmoil in the economics of the government.

\section{CONCLUSION}

Based on empirical facts, the interaction of monetary and fiscal policy is not causality. The results of testing the interaction of household consumption expenditure variables, government spending, interest rates and inflation do not show a causal relationship. Expansive fiscal policy, government spending has no effect in the short run, but in the long run it has a negative effect on aggregate household consumption expenditure. The government increases aggregate expenditure to cover the decline in household aggregate consumption expenditure due to a decrease in household real income. Policymakers should always cautious that excessive deficit levels and chronic deficits can become unsustainable, adversely affecting macroeconomic stability. Expansive monetary policy, lowering interest rates, increasing the money supply, has a positive effect in increasing aggregate household consumption expenditure. Expansive monetary policy is more effective in dealing with falling aggregate demand than expansionary fiscal policy in times of economic crisis due to the Covid-19 pandemic.
Inflation has no effect on aggregate household consumption expenditure in the short and long Inflation does not have an impact on the stability of aggregate household consumption expenditure in the short term, but do have an impact on the long term. Inflation does not affect aggregate expenditure because during the study period the inflation rate in Indonesia was stable, even tending to decline in the last two years. Some of the weaknesses of this study include the short observation period. This limitation arises because of the limited availability of data. To confirm the results of this study, further studies can use primary data through questionnaires to groups of households whose economic activity is disrupted due to the Covid-19 pandemic.

Some of the weaknesses of this study include, first, the short observation period. This limitation arises because of the limited availability of data. To confirm the results of this study, further studies can use primary data through questionnaires to groups of households whose economic activity is disrupted due to the Covid-19 pandemic. Second, the scope of the subject of observation is very broad (national level). The economic crisis due to Covid-19 is more pronounced in a densely populated province with the majority of economic activities in the trade, services and tourism sectors. Future researchers are expected to conduct research on the impact of the pandemic on aggregate demand at the provincial level.

\section{REFERENCES}

Dornbusch, R., Fischer, S., \& Startz, R. (2018). Macroeconomics. Mc Graw Hill.

Fischer, S., \& Modigliani, F. (1980). Towards and understanding of the real effects and costs of Inflation. 
National Bureau of Economic Research, -

Fitriani, F. F. (2020, Juni 2). https://ekonomi.bisnis.com/.

Retrieved February 5, 2021, from https://ekonomi.bisnis.com/:

https://ekonomi.bisnis.com/read/20 200602/9/1247591/inflasi-mei2020-007-persen-daya-beli-lemahakibat-covid-19-

Gujarati, N. D. (2003). Basic Econometric. Singapore: McGraw-Hill Education.

Illahi, N., Adry, M. R., \& Triani, M. (2018). Analisis Determinan Pengeluaran Konsumsi Rumah Tangga di Indonesia. Jurnal Ecogen, 549-556.

Julita, S. L. (2021, February 5). https://www.cnbcindonesia.com/. Retrieved February 5, 2021, from https://www.cnbcindonesia.com/: https://www.cnbcindonesia.com/ne ws/20210205063756-4-221192/rimasih-resesi-pdb-kuartal-iv-2020tumbuh-negatif-219

Muttaqim, H., Hamdani, \& Husin, D. (2019). Inflasi, Tingkat Suku Bunga, dan Konsumsi di Provinsi Aceh. Ekspansi: Jurnal Ekonomi, Keuangan, Perbankan dan Akuntansi, 285-295.

Nagayasu, J. (2017). Inflation and consumption of nontradable goods: Global implications from regional analyses. International Review of Economics \& Finance, 478-491.

Nainggolan, E. U. (2020, August 3). https://www.djkn.kemenkeu.go.id/. Retrieved February 4, 2021, from https://www.djkn.kemenkeu.go.id/: https://www.djkn.kemenkeu.go.id/ artikel/baca/13287/StrategiKebijakan-Pemulihan-EkonomiNasional.html

Nuru, N. Y. (2020). Monetary and fiscal policy effects in South African economy. African Journal of Economic and Management Studies, 11(4), 625-638.

Oo, T. L. (2019). The Effect of Fiscal Policy on Economic Growth in Myanmar. East Asian Community Review, 101-124.

Rahutami, A. I. (2007). Interaksi Kebijakan Moneter dan Fiskal: Dominasi atau Kausalitas. Kanisius, - .

Safriadi, Masbar, R., \& Syahnur, S. (2014). Efektifitas Antara Kebijakan Moneter dan Kebijakan Fiskal terhadap Perekomian Indonesia: Pendekatan Model IS-LM. Jurnal Ilmu Ekonomi Pascasarjana Universitas Syiah Kuala, 85-96.

Springer, W. L. (1977). Consumer Spending and the Rate of Inflation. The Review of Economics and Statistics, 59(3), 299-306.

Wiguna, D. K. (2021, January 4). Antaranews.com. Retrieved February 5, 2021, from Antaranews.com: https://www.antaranews.com/berita 11926436/bps-inflasi-2020-hanya168-persen-ini-inflasi-terendah

Zoto, O., \& Berisha, M. (2016). Budget Defcit and Economic Growth in Albania. International journal of engineering sciences and research technology., -. 